\title{
The Effect of Government Budget in Education and Health Sector, GRDP and Gini Ratio on the Human Development Index (IPM) n Makassar City
}

\author{
Nurdiana $^{1, *}$, Hajrah Hamzah ${ }^{2}$, Citra Ayni Kamaruddin ${ }^{3}$, Andi Tenri Ampa ${ }^{4}$ \\ ${ }^{1}$ Department of Economics Education, Faculty of Economics, Universitas Negeri Makassar, Makassar, Indonesia \\ ${ }^{2}$ Department of Accounting, Faculty of Economics, Universitas Negeri Makassar, Makassar, Indonesia \\ ${ }^{3}$ Department of Development Economics, Faculty of Economics, Universitas Negeri Makassar, Makassar, Indonesia \\ ${ }^{4}$ Department of Economics Education, Faculty of Economics, Universitas Negeri Makassar, Makassar, Indonesia \\ *Corresponding author. Email: diana@unm.ac.id
}

\section{ABSTRACT}

This review intends to decide the impact of government financial plans in the instruction and wellbeing area, Gross Regional Domestic Product (GRDP) and the Gini proportion to the Human Development Index (HDI) in the city of Makassar. This exploration is quantitative examination. The examination strategy utilized in this review is the Multiple Linear Regression investigation method.

Keywords: Government Budget in Education Sector, Health, GRDP, Gini Ratio and HDI.

\section{INTRODUCTION}

The Human Development Index (HDI) is an action used to quantify the accomplishment of advancement. Despite the fact that it doesn't quantify all elements of human turn of events, the HDI is thought of as fit for estimating the fundamental components of human turn of events. The expanding worth of HDI shows that there is an expansion in quality HR in a space [1].

The state of the Human Development Index (HDI) in the city of Makassar from 2007 to 2016 has expanded well consistently. These improvements can be found in the accompanying chart:

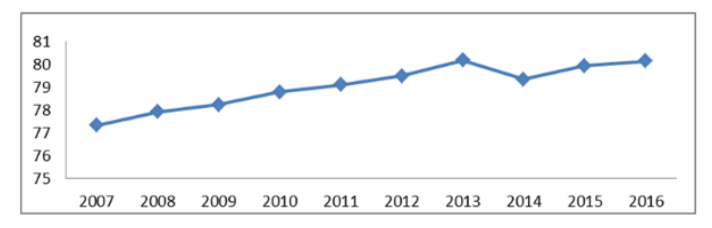

The chart or picture above shows the Makassar City Human Growth Index (IPM) over the most recent 10 years time frame, specifically from 2007 to 2016. From the chart, it very well may be seen that the Human Growth Index (HDI) of Makassar City in 2007 was 77.33 percent and kept on expanding until 2013 it arrived at 80.17 percent. Nonetheless, in 2014 the Human Growth Index (HDI) of Makassar City encountered a decay from 80.17 percent to 79.35 .

In empowering the job of people in the advancement cycle, venture is expected to get ready and make useful HR, which for this situation alludes to interest in schooling and wellbeing [2]. The advancement of a space can be estimated dependent on its principle marker, specifically instruction. Assuming that the degree of state funded schooling is high, the more prominent the chance for individuals to enter the universe of work [3]. As indicated by [4] Investment in training is totally essential, so the public authority should have the option to assemble a decent instructive office and framework. With the essential capital, specifically quality training, expanding financial development is not difficult to accomplish [5]. This implies that the public authority plays a part in deciding

Notwithstanding schooling, wellbeing is likewise significant in gathering fundamental human necessities. The degree of wellbeing will be extremely Another component that is thought to affect the HDI is the Gross Regional Domestic Product (GRDP). Gross Regional 
Domestic Product (GDP) is an action that is worldwide in nature and is an incorrect estimation of monetary development, since it can't mirror the genuine government assistance of the populace, despite the fact that truth be told government assistance should be appreciated by each inhabitant in the nation or locale concerned [6].

\section{LITERATURE REVIEW}

The Human Development Index (HDI) demonstrates pay disparity. Disparity of pay circulation will prompt the hole between the rich and the poor to extend. As indicated by Irma Aldeman and Cyntia Taft Morris [3], Inequality that happens in a space will influence the degree of local area government assistance in the district. The human improvement list and pay disparity have an interrelated relationship. As indicated by Becker [7], states that HDI negatively affects disparity.

Becker inspects all the more profoundly the job of formal instruction in supporting financial development expressing that the higher the conventional training acquired, the higher the efficiency of the labor force will be. This is as per the hypothesis of human resources in [6], to be specific that instruction impacts monetary development and will diminish pay variations since training assumes a part in expanding work efficiency. This hypothesis accepts that populace development is dictated by individual efficiency.

Assuming everybody has a higher pay on account of advanced education, the populace's financial development can be upheld, with monetary development either straightforwardly or by implication negatively affecting pay disparity. At the point when monetary improvement is demonstrated for money conveyance, financial development will consume most of the day to accomplish a high development rate. The other way around, on the off chance that advancement is more centered around accomplishing high development rates, the more noteworthy the chance of imbalance in pay appropriation [8]. So it very well may be seen that the human advancement file and pay imbalance have an interrelated relationship. As indicated by Becker [6].

\section{METHOD}

This exploration is quantitative examination. The sort of information utilized in this review is optional information as a yearly time series, beginning from 2007 to 2016. In this review, there are two factors from the five information to be tried, to be specific the reliant variable (bound) as the Human Development Index (Y) and free factors (autonomous) as the Education Sector Government Expenditure Budget (X1), Health Sector Government Expenditure Budget (X2), Gross Regional Domestic Product (X3), and Gini Ratio (X4).

To test the speculation, the logical device utilized is the various straight relapse model since it has more than one autonomous variable, in particular X1, X2, X3 and $\mathrm{X} 4$. Then, at that point, the reliant variable that is impacted by the free factor is communicated in the accompanying structure:

$\boldsymbol{Y}=\alpha+\beta_{1} X_{1}+\beta_{2} X_{2}+\beta_{3} X_{3}+\beta_{4} X_{4}+\varepsilon$

Where:

$\boldsymbol{Y}=$ Human Development Index (HDI)

$X_{1}=$ Education Sector Government Budget

$X_{2}=$ Health Sector Government Budget

$X_{3}=$ Gross Regional Domestic Product (GRDP)

$X_{4}=$ Gini Ratio

$\boldsymbol{\alpha}=$ Constant

$\beta_{1}-\beta_{4} \beta_{1}=$ Independent Variable Regression Coefficient

$\varepsilon=$ Error term Confounding variables or factors

Other than variables that are not included as mmodel variables above (residual error).

\section{DISCUSSION}

Multiple linear regression analysis is the analysis used to determine the effect of the variable government budget in the education sector (X1), government budget in the health sector (X2), gross regional domestic product (X3) and the Gini ratio (X4) to the Human Development Index (Y) in South Sulawesi Province. The results of the analysis will be shown in the following table:

Table 1. Effect of Variables X1, X2, X3 and X4 on $\mathrm{Y}$

\begin{tabular}{lcccc}
\hline Variabel & B & T & Sig. & Hasil \\
(Constant) & 77.008 & 45.598 & .000 & Sig. \\
$\begin{array}{l}\text { Anggaran } \\
\text { Pendidika }\end{array}$ & $9.646 \mathrm{E}-9$ & 7.543 & .001 & Sig. \\
$\mathrm{n}$ & & & & \\
$\begin{array}{l}\text { Anggaran } \\
\text { Kesehatan }\end{array}$ & $-7.641 \mathrm{E}-$ & -2.775 & .039 & Sig.
\end{tabular}




\begin{tabular}{lcccl} 
PDRB & $1.312 \mathrm{E}-8$ & 3.333 & .021 & Sig. \\
Rasio Gini & -11.050 & -1.921 & .113 & $\begin{array}{l}\text { Tidak } \\
\text { Sig. }\end{array}$ \\
R Square & & \multicolumn{2}{c}{.973} & \\
\hline
\end{tabular}

In view of the consequences of information handling contained in the table over that in the way investigation the worth utilized is the worth that lies in beta, so it will frame the accompanying relapse condition:

$\boldsymbol{Y}=\boldsymbol{a}+\beta_{1} X_{1}+\beta_{2} X_{2}+\beta_{3} X_{3}+\beta_{4} X_{4}$

In view of the aftereffects of information handling contained in the table over, the relapse condition can be depicted as follows:

$\boldsymbol{Y}=77.008+9.646_{X 1}-7.641_{X 2}+1.312_{X 3}-$ $11.050_{X 4}$

In light of the relapse condition, it very well may be seen that the importance worth of the training area government spending plan variable $(\mathrm{X} 1)$ is 0.001 . The consequences of the meaning of the $\mathrm{X} 1$ variable on $\mathrm{Y}<$ 0.05 , implying that the relapse result of the variable measure of government financial plan for the instruction area affects the Human Development Index (IPM). The consequences of this investigation are in accordance with research directed [2]. The ramifications of these discoveries is that expanding government spending on the instruction area has demonstrated to have the option to empower expanded monetary development through working on the nature of the Human Development Index (IPM), [5].

The importance worth of the wellbeing area government spending plan variable (X2) is 0.039 . The aftereffects of the meaning of the $\mathrm{X} 2$ variable on $\mathrm{Y}<$ 0.05 , implying that the relapse result of the variable number of government spending plans for the wellbeing area impacts the Human Development Index (HDI). The aftereffects of this examination are in accordance with research directed by Pratowo [7] that in long haul conditions, a country's financial development relies upon human advancement capital and it is important to divert state capital uses in the schooling area and wellbeing to build human improvement capital and wind up expanding monetary development as reflected in the Human Development Index (HDI).

The aftereffects of the third speculation examination can be seen that the importance worth of the Brotu
Regional Domestic Product (X3) variable is 0.021 . The aftereffects of the meaning of these factors on the Human Development Index $(\mathrm{HDI})<0.05$, implying that the relapse result of the gross territorial homegrown item (GRDP) variable altogether affects the Human Development Index (IPM). The consequences of this examination are in accordance with the exploration led. by Muliza [4] said that the gross territorial homegrown item impacts the quantity of destitute individuals.

The consequences of the fourth speculation investigation can be seen that the importance worth of the Gini Ratio (X4) variable is 0.113 . The consequences of the meaning of these factors on the Human Development Index $($ IPM $)>0.05$, so it shows that the result of the Gini Ratio variable relapse doesn't significantly affect the Human Development Index (IPM). This is in accordance with research directed by Hartini [3], just as going against or not in accordance with the aftereffects of examination led by Pratowo [7]. This implies that assuming the Gini proportion diminishes, the Human Development Index (IPM) will increment.

\section{CONCLUSION}

In light of the aftereffects of the information examination and conversation depicted above, it tends to be reasoned that the public authority financial plan factors in the training, wellbeing and Gross Regional Domestic Product (GRDP) areas impact the Human Development Index (IPM) in Makassar City. This implies that each time there is an increment in the public authority financial plan factors for the instruction, wellbeing and Gross Regional Domestic Product (GRDP) areas, it will build the Human Development Index (IPM). while the Gini proportion variable doesn't significantly affect the Human Development Index (IPM) so that assuming there is an adjustment of the Gini proportion, there will be no expansion in the Human Development Index (IPM).

\section{ACKNOWLEDGMENTS}

We thank the anonymous reviewers who have provided constructive suggestions for improving this article.

\section{REFERENCES}

[1] Bakhti. 2014. Bhakti \& Nadia Ayu. (2014). Analisis Faktor-Faktor yang Mempengaruhi Indeks Pembangunan Manusia di Indonesia periode 20082012. Jurnal Ekonomi dan Keuangan. 18(4):4. 
[2] Dianaputra, I Gede Komang Angga dan Aswitari, Luh Putu. 2017. Pengaruh Pembiayaan Pemerintah Di Sektor Pendidikan Dan Kesehatan Terhadap Indeks Kualitas Manusia Serta Perumbuhan Ekonomi Pada Kabupaten/Kota Provinsi Bali Tahun 2011-2015. E-Jurnal EP Unud, 6(3): h: 115-146.

[3] Hartini, Nita Tri. 2017. Pengaruh PDRB Per Kapita, Investasi dan Indeks Pembangunan Manusia terhadap Ketimpangan Pendapatan Antar Daerah di Provinsi Daerah Istimewa Yogyakarta Tahun 20112015. Jurnal Pendidikan dan Ekonomi. Volume 6, Nomor 6. Halaman 530-539.

[4] Muliza, dkk. 2017. Analisis pengaruh pengaruh belanja pemerintah pada sektor kesehatan dan pendidikan, tingkat kemiskinan serta Produk Domestik Regional Bruto (PDRB) terhadap Indeks Pembangunan Manusia (IPM) di Provinsi Aceh. Jurnal perspektif ekonomi Darussalam. Volume 3 Nomor 1. ISSN. 2502-6976. Halaman 51-69.

[5] Pake, Sal Diba Susen, George M.V. Kawung, Antonius Y. Luntungan. 2018. Pengaruh Pengeluaran Pemerintah Bidang Pendidikan dan Kesehatan terhadap Indeks Pembangunan Manusia (IPM) di Kabupaten Halmahera Utara. Jurnal Berkala Ilmiah Efisiensi Volume. Volume 18 Nomor 04. Halaman 13-22.

[6] Patta. 2012. Pengaruh pengeluaran Pemerintah di Sektor Pendidikan dan Kesehatan terhadap Indeks Pembangunan Manusia di Kabupaten Kutai Timur. Jurnal Ekonomi Pembangunan. Volume 1 Nomor 1. Halaman 25-42.

[7] Pratowo, I. Nur. 2012. Analisis Faktor- Faktor yang Berpengaruh terhadap Indeks Pembangunan Manusia. Jurnal Studi Ekonomi Indonesia. Volume 1 Nomor 1. Halaman: 15-31.

[8] Jurnal Ekonomi Pembangunan. Volume 8 No 2. Hal 125-146. 